\title{
A Tale of Two (Diverse) Countries: Religious Diversity in Canada and Singapore
}

\author{
Arif A. Jamal ${ }^{\star}\left(\mathbb{D}\right.$ and Daniel Wong Sheng Jie ${ }^{* *}$
}

(Received 22 April 2019; accepted 29 August 2019)

\begin{abstract}
Both Canada and Singapore express support for-and have the reality of being-multi-cultural, multi-ethnic, and multi-religious; and both jurisdictions have an avowed commitment to the freedom of religion. Yet, this commitment expresses itself in different ways in these two contexts. Although both the Canadian Charter of Rights and Freedoms and the Singaporean Constitution guarantee the freedom of religion, juridical definitions of what this freedom means may differ quite profoundly.

This Article explores and analyzes these two different environments that nonetheless share important features. We argue that the approaches of Singapore and Canada do not fall simply into the categories of being "liberal" or "illiberal," but instead invite reflection and reconsideration on the concepts of pluralism, secularism, and liberalism in interesting ways. This Article thus highlights the significance of contextual factors in understanding the ways in which religious diversity is dealt with, particularly in Canada and Singapore, but also more generally.
\end{abstract}

Keywords: Canada; Singapore; religious diversity; multiculturalism

\section{A. Introduction}

Singapore and Canada are in vastly different parts of the world but share some salient characteristics. Both are tremendously diverse in ethnic, racial, and—increasingly—religious terms. ${ }^{1}$ Both countries also embrace their diversity. For example, reference to the multicultural and multireligious character of both countries is common, both in general social discourse as well as by political actors and state officials. Indeed, both countries have commonly appreciated metaphors to describe themselves that emphasize their diversity: "rojak"2 in Singapore and the "mosaic" in Canada. Moreover-and more importantly for present purposes-both countries also express an avowed commitment to freedom of religion, which is constitutionally guaranteed. In Canada, this is found as the first of the "fundamental freedoms" guaranteed to Canadians under the Canadian Charter of Rights and Freedoms. ${ }^{3}$ In Singapore, Article 15 of the Constitution of the Republic of

\footnotetext{
${ }^{*}$ Faculty of Law, National University of Singapore (NUS Law).

${ }^{* *}$ NUS Law/Yale-NUS Double Degree Program, Class of 2021.

${ }^{1}$ For an account of Singapore's religious diversity, see Global Religious Diversity, PEw REs. CTR. (Apr. 4, 2014), http://www. pewforum.org/2014/04/04/global-religious-diversity/ (listing Singapore as having the highest religious diversity in the world).

${ }^{2}$ For the culinary and social sense of "rojak," see Rojak, SINGAPORE INFOPEDIA, http://eresources.nlb.gov.sg/infopedia/ articles/SIP_392_2005-01-06.html.

${ }^{3}$ Canadian Charter of Rights and Freedoms, Part I of the Constitution Act, 1982, being Schedule B to the Canada Act, 1982, c 11 (U.K.), which states at $\$ 2$ :

Fundamental Freedoms
}

(C) The Author(s) 2019. Published by Cambridge University Press on behalf of the German Law Journal. This is an Open Access article, distributed under the terms of the Creative Commons Attribution licence (https://creativecommons.org/licenses/by/4.0/), which permits unrestricted re-use, distribution, and reproduction in any medium, provided the original work is properly cited. 
Singapore provides for freedom of religion. ${ }^{4}$ Finally, both countries speak about their basic secularism. ${ }^{5}$

This Article concerns these two diverse and diversity-embracing countries. It compares and reflects upon their different state approaches, and in particular legal approaches, to managing religious diversity. We will seek to demonstrate that, on the one hand, the approaches in both jurisdictions do not fall neatly into a categorization of being "liberal" or "illiberal"; on the other hand, they are also not simply defined by their secularism or lack thereof. Rather, the different approaches in the countries invite us to reflect on pluralism, secularism, and liberalism but also highlight the weight of context in addressing the challenge of diversity. ${ }^{6}$

As a general statement, one might say that the predominant narrative with respect to religious freedom in Canada is that of upholding individual rights and liberties, while in Singapore it is the maintenance of "religious harmony," understood as social cohesion across the country's different ethnic, religious communities. ${ }^{7}$ That said, we need to unpack these headline statements, and we do so by first providing some context to both jurisdictions.

\section{Religious Diversity and Demographics: Canada}

A Pew Research Center report from 2013 highlights how Canada's religious landscape has experienced significant changes in recent years. ${ }^{8}$ Pew notes that:

Two-thirds of Canadians (including adults and children) identify either as Catholic or as Protestant, but both Christian groups have seen substantial erosion in their shares of the Canadian public ....9 Concurrently, the number of Canadians who belong to other religions_-including Islam, Hinduism, Sikhism, Buddhism, Judaism and Eastern Orthodox

Everyone has the following fundamental freedoms:

(a) freedom of conscience and religion;

(b) freedom of thought, belief, opinion and expression, including freedom of the press and other media of communication;

(c) freedom of peaceful assembly; and

(d) freedom of association.

${ }^{4}$ Constitution of the Republic of Singapore Aug. 9, 1965, art. 15, which states: Freedom of Religion

(1) Every person has the right to profess and practise his religion and to propagate it.

(2) No person shall be compelled to pay any tax the proceeds of which are specially allocated in whole or in part for the purposes of a religion other than his own.

(3) Every religious group has the right-

(a) to manage its own religious affairs;

(b) to establish and maintain institutions for religious or charitable purposes; and

(c) to acquire and own property and hold and administer it in accordance with law ....

${ }^{5}$ See Rosalie Jukier \& Jose Woehrling, Religion and the Secular State in Canada, in Religion and the SECUlar STATE: National Reports 185 (Javier Martinez-Torron \& W. Cole Durham eds., 2010); Jaclyn Neo, Secular Constitutionalism in Singapore: Between Equality and Hierarchy, 5(3) OxFORD J.L. \& RELIGION 431 (2016).

${ }^{6}$ See, e.g., John Rawls, Political Liberalism xxv (1993). One formulation of the challenge of dealing with diversity comes from John Rawls's famous question: "How is it possible that there may exist over time a stable and just society of free and equal citizens profoundly divided by reasonable religious, philosophical and moral doctrines?"

${ }^{7}$ For a discussion of the religious harmony narrative in Singapore, see Arif A. Jamal, Managing Religion through 'Religious Harmony': The Case of Singapore, in Religions Rules, State Law, and Normative Pluralism-A Comparative Overview 325 (Rossella Bottoni et al. eds., 2016).

${ }^{8}$ Canada's Changing Religious Landscape, PEW RES. CTR. (June 27, 2013), http://www.pewforum.org/2013/06/27/canadaschanging-religious-landscape/.

${ }^{9} I d$. (reporting that from 1981 to 2011, the percentage of Canadians who identify as Catholic dropped from $47 \%$ to $39 \%$, while those who identify as Protestant declined from $41 \%$ to $27 \%$ ). 
Christianity-is growing. Collectively, these smaller religious groups account for more than one-in-ten Canadians (11\%) as of 2011, up from not quite one-in-twenty (4\%) in $1981 .^{10}$

So, Canada's religious adherents are becoming significantly more diverse over the decades. And immigration is a key part of this story. While in the 1980s, a majority (56\%) of immigrants to Canada identified as either Catholic or Protestant, Pew reports that since 2001, about four-inten (39\%) new Canadian immigrants have belonged to religious minorities; for example, Eastern Orthodox Christianity, Islam, Buddhism, Sikhism, Hinduism, and Judaism. As immigrants compose about $20 \%$ of Canada's population, this more varied religions affiliation has changed the religious dynamics in the country.

The proportion of Canadians expressing no religious affiliation appears to be an equally significant change. Pew reports that this percentage has increased from $4 \%$ in 1971 to $24 \%$ (23.9\% according to census figures) in 2011-a six-fold increase. This has also been accompanied by a significant decrease in attendance at religious services in Canada. In 1986, 43\% of Canadians aged fifteen years and above attended religious services at least once a month; but by 2010, this had dropped to $27 \%$. Finally, analyzing the trend lines reveals interesting conclusions. Pew notes that the percentage of religious non-affiliation-the "nones"-is higher among younger age cohorts. The report notes:

Recent generations of Canadians are significantly less affiliated than earlier generations. For example, 29\% of Canadians born between 1967 and 1986 have no religious affiliation as of 2011, 17 percentage points higher than Canada's oldest living generation (born 1946 or earlier) and nine points higher than Canadians born between 1947 and 1966. ${ }^{11}$

If this trend continues in the same direction for post-1986 cohorts, then Canada can be expected to have an increasingly religiously unaffiliated population in the future. Combined with the greater range of religions adhered to among the religiously affiliated, the upshot is of heightened diversity.

\section{Religious Diversity and Demographics: Singapore ${ }^{\mathbf{1 2}}$}

In its 2014 ranking of religious diversity in different countries, Pew reported that Singapore was the country with the highest religious diversity in the world, and provided the headline that "Half of the Most Religiously Diverse Countries are in Asia-Pacific Region." ${ }^{13}$ Singapore's ethnic "rojak" of Chinese, Malay, Indian, and others is reflected as a religious rojak of Buddhists and Taoists (primarily ethnically Chinese), Hindus (primarily Indian), Muslim (mainly Malay, but also with Indian Muslim, and Arab components), Christians (often Chinese and Eurasian, as well as Indian), and smaller numbers of Sikhs, Jains, and Jews. Moreover, Singapore has had a religiously diverse population for much of its history, so one might say that it is accustomed to religious variety. Singapore's demographics also show that its religious mix is relatively stable over time with approximately $15 \%$ to $20 \%$ Christians, $14 \%$ to $15 \%$ Muslim, $44 \%$ to $50 \%$ Buddhist/ Taoist, $5 \%$ Hindus, and under $1 \%$ other religions. "No religious affiliation" has been growing from

\footnotetext{
${ }^{10}$ This information is also found in Government of Canada census data. See Two-thirds of the Population Declare Christian as Their Religion, STAT. CAN. (Feb. 19, 2016), https://www150.statcan.gc.ca/n1/pub/91-003-x/2014001/section03/33-eng.htm.

${ }^{11}$ Canada's Changing Religious Landscape, supra note 8.

${ }^{12}$ For an account of the historical development of Singapore's demographics and religious diversity, see Kevin YL Tan \& Matthias Roßbach, State Answers to Religious Diversity in Germany and Singapore: History, Philosophy, and Strategy, 20 German L.J. XX, Section C (2019).

${ }^{13}$ Global Religious Diversity, supra note 1 (giving Singapore a religious diversity score of 9.0 out of 10, higher than anywhere else).
} 
under $15 \%$ in 2000 to $18.3 \%$ in $2015,{ }^{14}$ and among younger cohorts, "no religious affiliation" is even higher at $23 \%$ of $15-24$ year olds and $22.4 \%$ of $25-34$ year olds versus only $14.6 \%$ of those 55 and older and $16.8 \%$ of $45-54$ year olds. In other words, similar to Canada, the current trend is towards the decreasing of religious affiliation.

\section{Unpacking and Framing the Political Contexts}

Both Canada and Singapore have a commitment to - and the reality of being-multi-cultural, multi-ethnic, and multi-religious, and both have an avowed commitment to the freedom of religion. However, this commitment expresses itself in different ways in these two contexts. Though, as mentioned above, both the Canadian Charter of Rights and Freedoms and the Constitution of Singapore guarantee the freedom of religion, juridical definitions of what this freedom means may differ quite profoundly. A general statement could therefore be made that the predominant narrative regarding religious freedom in Canada is that of upholding individual rights and liberties, while that of Singapore would be the maintenance of social cohesion between the different ethnic, religious, and other groups.

What explains these differences? Benjamin Berger suggests approaching law as culture in the study of law and religion because applying a purely legal or ideal-theoretic method would leave gaps in the study with regards to "lived realities, the experience of power, and law's role in both." 15 Understanding each jurisdiction's rule of law in this manner would take as its "primary focus the particular way the law shapes and gives meaning to experience and, given that particularity, the way that it can itself be experienced."16 Invoking culture would have the benefit of going beyond pure juridical and moral reasoning, and would situate law's understanding of religion within its wider "webs of significance."

On this reading of law as culture, the law ceases to be something that is "autonomous, universal, and transparent." 18 The law, therefore, must understand religion through its own fundamental intuitions and give meaning to its experience as such. If Berger is correct, then a backward analysis would also be possible - that is, looking at the legal reasoning of decisions could equally shed light on the fundamental normative commitments held by each legal culture.

This approach might be located as part of a broader law in context methodology. The law in context movement-associated with William Twining, as well as other scholars—suggests that we should see law as linked to its social context(s) in a dialogical manner. As Twining states: "[I]n order to understand law in the world today it is more than ever important to penetrate beneath the surface of official legal doctrine to reach the realities of all forms of law as social practices." 19 Methodologically, we therefore adopt the view that law is connected to its social contexts, is part of social practice(s), and is intimately linked to culture.

In this framework, it would also appear that the government in Canada adopts a more handsoff approach than the Singaporean state. The latter has a reputation of micromanaging the affairs of different ethnic and religious groups. For example, public housing in Singapore applies an Ethnic Integration Policy whereby the Housing Development Board would ensure a "balanced mix of the various ethnic communities" through applying certain ethnic quotas in order to promote racial integration and harmony. ${ }^{20}$ Furthermore, all religious groups are required to be

\footnotetext{
${ }^{14}$ Key Indicators of Resident Population and Resident Households, STAT. SING. (2015), https://www.singstat.gov.sg/-/media/ files/publications/ghs/ghs2015/indicators.pdf.

${ }^{15}$ Benjamin L. Berger, Law's Religion: Religious Difference and the Claims of Constitutionalism 35 (2015).

${ }^{16} I d$. at 37.

${ }^{17} I d$. at 38 .

${ }^{18} \mathrm{Id}$. at 106.

${ }^{19}$ William Twining, General Jurisprudence: Understanding LaW from a Global Perspective 7 (2009).

${ }^{20}$ Ethnic Integration Policy and SPR Quota, HousING \& DEv. BOARD (Dec. 29, 2017), https://www.hdb.gov.sg/cs/infoweb/ residential/buying-a-flat/resale/ethnic-integration-policy-and-spr-quota.
} 
registered under the Societies Act and are subject to governmental scrutiny. ${ }^{21}$ In contrast, such tight control is absent in Canada, and the number of ethnic enclaves has been allowed to rise from just six in 1981 to 260 in $2012 .{ }^{22}$ The Canadian law also does not require religious groups to register, though tax-exempt status may be granted by the state for groups that are registered as nonprofit organizations. ${ }^{23}$

From these broad strokes, it may appear that religious freedom as defined in a "Western liberal" sense is more constrained in Singapore than it is in Canada. Yet, a deeper analysis by viewing law as culture and considering the interaction with law and other religious cultures as cross-cultural encounters indicates that Singapore's rule of law may not afford less religious freedom than Canada's rule of law. Rather, the presuppositions internal to each respective rule of law's own culture are inherently different. Thus, the manifestation of religious freedom would diverge since both legal cultures begin with a different set of commitments.

\section{B. Discerning the Normative Commitments of Each Country}

Comparing and contrasting the different ways the courts in the two jurisdictions decide on cases that share a similar fact pattern can help us uncover the different normative commitments they possess.

\section{Judicial Approaches to Defining Religion}

The Canadian case of Donald v. Board of Education for Hamilton ${ }^{24}$ involved the suspension of two infant appellants from school due to their refusal on religious grounds to repeat the pledge of allegiance and to salute the flag. Likewise, the Singaporean decision in Nappalli Peter Williams v. Institute of Technical Education ${ }^{25}$ involved the suspension of the appellant Training Officer due to his refusal to participate in the pledge and anthem ceremony because of his religious convictions. The appellants in both cases were Jehovah's Witnesses.

In Donald, the court found for the appellant on statutory grounds, holding that the suspension contravened a statute that specifically provided that those who objected on religious grounds to saluting the flag or singing the national anthem were entitled to refrain from participation without forfeiting their right to attend school. Whereas, the Nappalli court found that the appellant's dismissal was not unconstitutional as it did not infringe upon his religious freedom.

Though the Donald decision did not directly engage provisions of the Canadian Charter regarding religious freedom-being decided well before the Charter came into existence-the court's discussion of how religion should be defined employs the language of what we might call liberal constitutionalism. Indeed, the very fact that the decision predates the Charter may show the historical pervasiveness of Canadian law's normative commitment towards liberally-crafted values.

The discussion of religious freedom in Donald can now be understood in light of Berger's account of how religion is viewed by the culture of Canadian constitutionalism. Thus, it may be no surprise that religious freedom in Canada is set in terms that revolve around the individual as the basic units of society, given the presence of a liberal temper in Canadian culture. ${ }^{26}$ After all,

\footnotetext{
${ }^{21}$ Societies Act 2014, c. $311 \S 4$ (Sing.).

${ }^{22}$ Tristin Hopper, Canada: As Immigration Booms, Ethnic Enclaves Swell and Segregate, NAT'L PosT (Feb. 112012 , 4:31 PM), https://nationalpost.com/news/canada/canada-as-immigration-booms-ethnic-enclaves-swell-and-segregate.

${ }^{23}$ U.S. Dep't of State, Bureau of Democracy, H.R. and Lab., 2017 International Religious Freedom Report-Canada 3 (2017), https://www.state.gov/wp-content/uploads/2019/01/Canada-2.pdf.

${ }^{24}$ Donald v. Bd. of Educ. for Hamilton, [1945] O.R. 518 (Can.).

${ }^{25}$ Nappalli Peter Williams v. Inst. of Tech. Educ., [1999] 2 S.L.R.(R.) 529 (Sing.).

${ }^{26}$ Further judicial support for this can be found in R. v. Big M Drug Mart, [1985] 1. S.C.R. 295, para. 122 (Can.), where Judge Dickson found "that an emphasis on individual conscience and individual judgment also lies at the heart of [the Canadian]
} 
premiating and focusing on the individual as the basic social, legal, and rights-bearing unit might be thought of as a cardinal liberal position. This conception of freedom defines religion as 1) essentially individual, 2) centrally addressed to autonomy and choice, and 3) private. ${ }^{27}$

Given this cultural background, the court was careful not to "proceed on any personal views on what (religious meaning) such exercises might include or exclude." ${ }^{28}$ Therefore, it rejected the respondent's argument that the flag salute does not connote religious significance but is merely meant to inculcate love and loyalty to one's country. More significantly, Gillanders JA, delivering the majority judgment, expressed his personal view that it was "difficult to understand how any well-disposed person could offer objection to joining in such a salute on religious or other grounds," yet he maintained that his own personal views should be disregarded. ${ }^{29}$ To accept the respondent's argument or subject the appellant to a judicial definition of religion would strip the appellants' autonomy to hold their own private religious beliefs. Each individual is thus given the right to define for herself what religious meanings to draw from each activity, thereby drawing for herself the line between the religious and the non-religious.

The manner in which the Singapore Court of Appeal in Nappalli adjudicated the issue was starkly different. The appellant argued that the technical educational institution's policy that required him to participate in the pledge ceremony was unconstitutional because it offended his fundamental rights as enshrined in the Constitution. In the court's judgment, there was a clear imputation of the Court of Appeal's own opinion of what acts could hold religious meaning. Even more significant is the strong language the court endorsed, that not only privileges its own opinions on what constitutes religious belief but also has the effect of representing these opinions as self-evident and the only ones that can hold any kind of credence. Thus, the Court of Appeal upheld the trial judge's ruling that stated that the National Anthem was "obviously not a religious ceremony." 30 Instead, the court drew a distinction between philosophical choices and religious ones. Citing the lower court decision of Thomas v. Review Board of Indiana Employment Security Division ${ }^{31}$ having the perception that a pledge ceremony has religious meaning would be a philosophical choice rather than a religious one, and thereby this philosophical choice would not be entitled to the protection of the Constitution. In expressing this philosophical choice as a religious one, it was "clear" to the court that the appellant's interpretation of this activity "was a distortion of secular fact into religious belief." ${ }^{2}$

In the same vein, the court assertively stated that the appellant's interpretation of the act would be "excruciatingly absurd," as it would rob the Constitution of any operative effect. Article 16(3) of the Constitution states that "[n]o person shall be required to receive instruction in or to take part in any ceremony or act of worship of a religion other than his own." 33 The court's reasoning was that to interpret the act of pledge taking as religious would create an internal contradiction whereby the same Constitution that guarantees religious freedom would simultaneously encroach on this freedom by coercing participation in a religious ceremony. ${ }^{34}$

The court also sought to distinguish the facts presented to it from those in Donald by highlighting the fact that Canada's religious anthem consisted of a prayer hymn that reflected some religious character, while Singapore's anthem was purely secular and had no religious under-

\footnotetext{
democratic political tradition. The ability of each citizen to make free and informed decisions is the absolute prerequisite for the legitimacy, acceptability, and efficacy of [the Canadian] system of self-government."

${ }^{27}$ BERGER, supra note 15 , at 66 .

${ }^{28}$ Donald, supra note 24 , at 530 .

${ }^{29} \mathrm{Id}$.

${ }^{30}$ Nappalli, supra note 25, at para. 22 (emphasis added).

${ }^{31}$ Thomas v. Review Bd. of Ind. Emp't Sec. Div., 391 N.E.2d 1127 (1979).

${ }^{32}$ Nappalli, supra note 25 , at para. 28.

${ }^{33}$ Constitution of the Republic of Singapore Aug. 9, 1965, art. 16(3).

${ }^{34}$ Nappalli, supra note 25 , at para. 29.
} 
tones. ${ }^{35}$ Yet, in doing so, the court ignored the line of United States decisions that Donald cites, which highlights the variety of ways different individuals may interpret symbols. Judge Lehman in New York v. Sandstorm ${ }^{36}$ observed:

There are many acts which are not acts of worship and which for most men have no religious significance and are entirely unrelated to the practice of any religious principle or tenet, but which may involve a violation of an obligation which other men may think is imposed upon them by divine command or religious authority. ${ }^{37}$

Thus, the fact that Singapore's national anthem is professedly secular in substance may not detract from the fact that an individual can deem the very act of professing allegiance to the state to be in contravention of her religious beliefs.

Considering Nappalli with Donald as a foil suggests that in Singapore the liberal value of individualism in the understanding of the rule of law does not hold-or rather, does not hold as strongly - as it does in Canada. The individual opinion that the appellant held could easily be defeated by the "objective, external view of what would constitute religion and, concomitantly, what practices had a religious character." ${ }^{38}$ As Jaclyn Neo observes, this position fails to accord due weight to the sincere belief of individuals. Further, it places a great legal burden on the individual to prove that her religious belief is indeed religious in character-she is forced to prove that her religious beliefs are worthy of constitutional protection. ${ }^{39}$ Hence, Neo suggests a "deferential approach" to the definition of religion, where the exercise of defining a religion would be shifted from the hands of the judiciary to the hands of the individual applicant or religious group. Such a subjective approach would take seriously and weigh in favor of a religious group's self-definition.

Neo cites the case of Vijaya Kumar s/o Rajendran v. Attorney-General as an example of the Singapore judiciary arguably applying such a deferential approach. In that case, the applicants were challenging a state policy to ban the playing of musical instruments during foot processions that were in celebration of a Hindu festival known as Thaipusam. The court was posed with the question of whether or not the playing of musical instruments was "an essential part of Thaipusam procession." ${ }^{40}$ Unlike the case of Nappalli, the court did not engage in its own interpretation of whether the act had any connected religious meaning. Instead, it deferred to the firm belief of the applicants and their expert witness and held that this sincere self-definition would be sufficient for the playing of musical instruments during Thaipusam to constitute an essential religious practice.

While it would appear that the decision in Vijaya is similar to that in Donald in that the court refrains from imposing its own external view of what religion constitutes, the different manners in which the jurisdictions have regard for expert opinion is reflective of the normative commitments that their legal cultures hold.

In Vijaya, the court deferred to the opinions of a Hindu expert in holding that the playing of such musical instruments could be an essential part of the religious activity. Furthermore, the court went further in recognizing that whether or not the playing of musical instrument was an essential practice in Hindu religion may differ when comparing one Hindu community from another. It acknowledged that "[r]eligious practices and rituals do vary from place to place and among different groups of believers in the same faith." 41

\footnotetext{
${ }^{35} I d$. at para. 25 .

${ }^{36}$ N.Y. v. Sandstorm, 279 N.Y. 523, 535 (1939).

${ }^{37} \mathrm{Id}$.

${ }^{38}$ Jaclyn Neo, Definitional Imbroglios: A Critique of the Definition of Religion and Essential Practice Tests in Religious Freedom Adjudication, 16(2) INT'L J. Const. L. 574, 581 (2018).

${ }^{39} I d$. at 593.

${ }^{40}$ Vijaya Kumar s/o Rajendran v. Attorney-General (2015), Sing. High Ct. 244, para. 19.

${ }^{41}$ Vijaya, Sing. High Ct. 244, para. 21.
} 
In contrast, the Supreme Court of Canada, in the case of Syndicat Northcrest $v$ Amselem, clearly expressed that any expert opinion adduced in an attempt to prove that a religious belief is sincere would not only be redundant but also contrary to the freedom of religious belief itself. Thus, the court stated that:

An "expert" or an authority on religious law is not the surrogate for an individual's affirmation of what his or her religious beliefs are. Religious belief is intensely personal and can easily vary from one individual to another. Requiring proof of the established practices of a religion to gauge the sincerity of belief diminishes the very freedom we seek to protect. $^{42}$

Thus, this judgment again reflects the Canadian legal culture's emphasis on the individual as the locus for religious freedom. As Berger puts it, "[r]eligion is, at root, a personal rather than social phenomenon and is located in the individual, not group-based." ${ }^{\prime 3}$ In comparison, though Singapore's judiciary "demonstrated sensitivity to the possibility of internal interpretational diversity and local particularities" 44 of religions, it is reluctant-as in the case of Nappalli-to allow an individual to define for herself the boundaries between the religious and non-religious. The smallest unit that is capable of self-definition is not the individual, but a small community or group.

Mathews Mathew has suggested that perhaps there is an "'Asian' conceptualization of religious freedom which differs from what Western societies may be comfortable with." Such a conceptualization emphasizes the "value of the cohesiveness of society" in the place of individual rights. ${ }^{45}$ If the conception of religious freedom in Canada was molded by the central intuition of upholding individual rights following its spirit of liberal constitutionalism, the conception of religious freedom in Singapore could be seen as shaped by the view that the law's central role is to maintain the cohesiveness of society rather than to uphold some abstract neo-Kantian individual rights. ${ }^{46}$

\section{Hate Speech and Religious Harmony}

The previous comparison between how each jurisdiction approaches the definition of religion shows how they correspondingly allow either the individual or the group as the smallest unit capable of self-definition and how this is indicative of the jurisdiction's predominant commitment to either the individual or to community and society. A comparison between how each jurisdiction treats hate speech directed at religious groups shows, reiterates, and reinforces this difference in commitments. This difference is made even more pronounced by the involvement of an additional liberally conceived constitutional right to the freedom of speech.

\footnotetext{
${ }^{42}$ Syndicat Northcrest v. Amselem, [2004] 2 S.C.R. 551, 583 (Can.). See also the famous statement of the European Court of Human Rights in Kokkinakis v. Greece, App. No. 14307/88, paras. 31-32 (May 25, 1993), http://hudoc.echr.coe.int/eng? $\mathrm{i}=001-57827$, in which the Court said:

As enshrined in Article 9 (art. 9), freedom of thought, conscience and religion is one of the foundations of a "democratic society" within the meaning of the Convention. It is, in its religious dimension, one of the most vital elements that go to make up the identity of believers and their conception of life, but it is also a precious asset for atheists, agnostics, sceptics and the unconcerned. The pluralism indissociable from a democratic society, which has been dearly won over the centuries, depends on it. While religious freedom is primarily a matter of individual conscience, it also implies, inter alia, freedom to "manifest [one's] religion." Bearing witness in words and deeds is bound up with the existence of religious convictions.

${ }^{43}$ BERGER, supra note 15 , at 69 .

${ }^{44} \mathrm{Neo}$, supra note 38 , at 585 .

${ }^{45}$ Mathews Mathew, Understanding Religious Freedom in Singapore, 11(2) ReV. FAITH \& INT'L AfF. 28, 34 (2013).

${ }^{46}$ See also Thio Li-Ann, Irreducible Plurality, Indivisible Unity: Singapore Relational Constitutionalism and Cultivating Harmony Through Constructing a Constitutional Civil Religion, 20 GERMAN L.J. XX, 6 (2019) (“Singapore's constitutional experiment to manage ethnic and religious diversity ... is constructed as a strategy to secure social harmony within the world's most religiously diverse polity, through recognizing an irreducible plurality in ethnic and religious terms, while maintaining an indivisible unity through nurturing bonds of solidarity.").
} 
Here, we will discuss and contrast two cases from the different jurisdictions. In the case of Public Prosecutor v. Amos Yee Pang Sang, the accused had posted a video online that labelled Jesus Christ as "power hungry," "malicious," and "deceptive," and opined that "Christians have no real knowledge of the Bible which is being manipulated by the "work of a multitude of priests." 47 In the Canadian case of R. v. Ahenakew, the accused made comments in a public speech claiming that the Jews were responsible for starting World War II and later told a newspaper reporter that the purpose of the Holocaust was to "get rid of a disease" and "clean up the world." ${ }^{48}$ While the accused was convicted in the former case, the accused in the latter case was not convicted.

What is interesting are the different natures of the provisions relied on by the prosecution/ Crown, which once again reflect the notion that the manner in which the law encounters religious matters is ultimately colored by law's central commitments. Yee was prosecuted under Section 298 of the Penal Code, which makes it an offense if one with deliberate intention of wounding the religious feelings of any person causes any matter however represented to be seen or heard by that person. ${ }^{49}$ Ahenakew was prosecuted under Section 319(1) of the Criminal Code, which states that "[e]very one who, by communicating statements, other than in private conversation, willfully promotes hatred against any identifiable group is guilty of ... [an offense]." 50

A notable difference is that the mens rea requirement is much harder to fulfill for Section 319(1) than it is for Section 298. The court in Amos Yee stated that to wound the religious feelings of a person "simply means to give offence to any person." ${ }^{11}$ In reaching its decision on whether or not this element of intention was met, the court found the character of the contents of the video "determinative." By pointing out similarities between Jesus and the late Singapore Prime Minister Lee Kuan Yew-such as how they were both "power hungry" and "malicious"-with the awareness that these comments would be offensive to the Christian population, the element of intention was satisfied. This is in contrast with the stringent mens rea requirement in Ahenakev, where the Crown was required to prove that the accused had intentionally promoted hatred. On the facts, the court considered the context in which this statement took place, which was at a conference between the leaders of the First Nation of Saskatchewan regarding a new federal policy. The court found that Ahenakev's speech had the purpose of influencing the audience and leadership of the proper course of action regarding the policy, and not to promote hatred against the Jewish people. ${ }^{52}$ Thus, though the court found that the statements were "revolting, disgusting and untrue," a conviction did not result. Beyond Ahenakev, the narrow mens rea requirement has resulted in only very few cases where the accused was actually convicted. ${ }^{53}$

Another notable difference is that while Section 319(2) requires that the offending statement be made in contexts other than in private conversation, a charge under Section 298 can be made even if the offending representation is made to a single individual. It is clear from the decision in Ahenakev and the prior decision of $R v$. Keegstra that Section 319(2) does not apply to "private conversations," and even excludes expressions of hatred in a place accessible to the public. ${ }^{54}$ Therefore, the audience of the offending statement is starkly different from Amos Yee. The defense in Amos Yee attempted to argue that the relevant section makes reference to "any person," and therefore it is "only meant to criminalize words, gestures or representation that is directed at a person and not at the entire religious community." 55 The court, however, rejected this argument, citing the Section 2 of the Interpretation Act which states that, "[w]ords and expressions in the

\footnotetext{
${ }^{47}$ Pub. Prosecutor v. Amos Yee Pang Sang (2015), Sing. D. Ct. 215, para. 32.

${ }^{48}$ R. v. Ahenakew (2009), 329 Sask. R. 140, para. 30 (Can. Sask. Prov. Ct.).

${ }^{49}$ Penal Code 2008 c. $244 \$ 298$ (Sing.).

${ }^{50}$ Canada Criminal Code, R.S.C. 1985, c. C-46 $\$ 319(1)$.

${ }^{51}$ Amos Yee, supra note 47 , at para. 32.

${ }^{52}$ Ahenakew, supra note 48 , at para. 39.

${ }^{53}$ See, e.g., Jukier \& Woehrling, supra note 5.

${ }^{54}$ R. v. Keegstra, [1990] 3 S.C.R. 697, 773 (Can.).

${ }^{55}$ Amos Yee, supra note 47, at para. 29.
} 
singular include the plural and words and expressions in the plural include the singular," and thus that "any person" would include both an individual and a class of persons. ${ }^{56}$ Moreover, the offending statement need only be "in the sight of that person, or causes any matter however represented to be seen or heard by that person." 57

From the decisions above, it is evident that the ambit of Section 298 is comparatively much wider than that of Section 319(2). The latter requires an active intention to incite hatred, while the former merely requires the intention to offend a group or even an individual using racial or religious slurs. The underlying reason for the decision in Amos Yee was ultimately the maintenance of religious harmony: "Religion is a very sensitive and passionate subject. We pride ourselves on our multi-ethnic and multi-religious society where everyone is free to practice his religion .... Pejorative remarks have the potential to cause social disorder." 58

It appears that the underlying commitment to the maintenance of social harmony has shaped the manner in which the law approaches matters concerning religious groups. Religious freedom is conceived in this manner not just as a freedom to practice one's beliefs but also a freedom from discrimination that may arise from religious difference. Thus, Jereza observes:

More than the freedom to practice, the right to religious freedom demands social, political, and economic inclusion of every person no matter what faith they profess, if they profess any faith at all. The freedom to profess and exercise one's religious beliefs would not be meaningful if the free expression of one's beliefs opens one to the possibility of discrimination, institutional marginalization, and, as is the reality for some, isolation from one's family and community or even death. ${ }^{59}$

Preventing the wounding of religious feelings of a certain group could therefore justify the lower mens rea requirement if it is felt that the state has a duty not only to ensure that religious groups are free to practice their religions but also ensure that they are free from acts of social exclusion.

The Canadian decision of Ahenakev should be understood within a wider jurisprudential backdrop. In the previous decision of Keegstra, the slim 4-to-3 majority was forced to construe Section 319 (2) in a narrow manner in order to allow it to survive the constitutional challenge that the accused had raised. The accused argued that Section 2(b) of the Canadian Charter protects the freedom of expression, and this included the communication of expressions that would promote hatred. Both the majority and minority agreed that Section 319(2) represents an infringement of this constitutional right. Nonetheless, while the majority held that Section 319(2) constitutes a reasonable limit upon the freedom of expression, the minority found that it would be to the detriment of democracy and of individual rights and freedoms.

Though it would appear that liberal constitutionalism was not fully successful in defining the relationship that society at large should have with religion in Canada, it did make a significant impact in pushing the majority in Keegstra to confine the ambit of the provision by adopting narrow definitions of the constituent terms of its test. The word "promote" was taken to exclude "simple encouragement or advancement," but only include "active support or instigation"; 60 while the term "hatred" - though recognized to carry many potential meanings — was "circumscribed so as to cover only the most intense form of dislike," 61 "a most extreme emotion that belies reason," which "if exercised ... implies that those individuals are to be despised, scorned, denied respect and made

\footnotetext{
${ }^{56}$ Amos Yee, supra note 47 , at para. 30.

${ }^{57}$ Penal Code 2008 c. $244 \$ 298$ (Sing.).

${ }^{58}$ Amos Yee, supra note 47 , at para. 81 .

${ }^{59}$ Veronica Louise B. Jereza, Many Identities, Many Communities: Religious Freedom Amidst Religious Diversity in Southeast Asia, 14(4) Rev. FaITH \& INT'L AfF. 89, 91 (2016).

${ }^{60}$ Keegstra, supra note 54 , at 776.

${ }^{61} \mathrm{Id}$. at 778 .
} 
subject of ill-treatment on the basis of group affiliations." 62 As a result, when Section 319(2) was applied in the case of Ahenakev, its scope was too narrow for the offending statements to be caught, because the accused could not be said to have intended to instigate hatred.

Counterintuitively, to more effectively promote religious and racial harmony between groups, Section 298 requires only that an individual is targeted; while in ensuring that Section 319(2) is constitutional in not placing too unreasonable an impediment on the individual's free speech, the Canadian equivalent requires a group to be the target.

Perhaps even more interesting in the Singaporean context is the judicial elevation of an ethnic or religious group's right to be free from offense into one that bears enormous constitutional weight when balanced against the constitutional right to freedom of speech. ${ }^{63}$ While the Singapore judiciary has found that the right to freedom of offense and other societal interests should be weighed against the freedom of speech in a "delicate balancing exercise," ${ }^{4}$ it would appear that once such a competing right of a group or societal interest arose, the incursion on the individual's freedom of speech would almost categorically be permitted. This once again reflects a concern for the preservation of harmony between the different groups, perhaps at the expense of the individual. The Singapore High Court has gone so far as to use "individualism" as a kind of dirty word, and a concept inimical to the rule of law:

While the clarion call for unfettered individual rights is almost irresistibly seductive, it cannot, however, be gainsaid that individual rights do not exist in a vacuum. Permitting unfettered individual rights in a process that is value-neutral is not the rule of law. Indeed, that form of governance could be described as the antithesis of the rule of law-a society premised on individualism and self-interest. ${ }^{65}$

In contrast, even though the Supreme Court of Canada in Keegstra found Section 319(2) constitutional, it did so with considerable reluctance and only after assuaging its own fears that the provision would unduly encroach on individual self-development. The justification for the provision against hate speech was not the victimized group's right to be free from offense. Instead, the court found that in addition to being in line with the state's multicultural aspirations, restricting hate speech could be justified because it "contributes little to the aspirations of Canadians or Canada in either the quest for truth, the promotion of individual self-development or the protection and fostering of a vibrant democracy." 66

Thus far we have explored some judicial responses to conflicts that arise due to the two jurisdictions' multicultural realities, and how these reflect the state's normative commitments. In Section $\mathrm{C}$, we apply a more theoretical and critical lens to state responses to multiculturalism, with the aim of moving beyond the categorization of each state as being liberal or non-liberal-or being more interested in individualism or communitarianism-to examine whether or not the states accept the multicultural elements they are faced with or are merely tolerant of them.

\section{Law and Religion as Cross-Cultural Encounter}

Berger points out that law is inherently jurispathic, and in its encounter with other normative arrangements and interpretations it supersedes and overrides them. ${ }^{67}$ In complementary fashion, Fred Dallmayr provides a taxonomy of "modes of cross-cultural encounter." ${ }^{68}$ Of interest are the

\footnotetext{
${ }^{62} \mathrm{Id}$. at 777 .

${ }^{63}$ Pub. Prosecutor v. Koh Song Huat Benjamin \& Another Case (2005), Sing. D. Ct. 272, para. 8.

${ }^{64}$ Chee Siok Chin v. Minister for Home Affairs, [2006] 1 S.L.R.(R.) 582, para. 52 (Sing.).

${ }^{65}$ Id (emphasis added).

${ }^{66}$ Keegstra, supra note 54 , at 701.

${ }^{67}$ BERGER, supra note 15 , at 103 .

${ }^{68}$ Berger, supra note 15 , at 103 ; see also Fred Dallmayr, Beyond Orientalism: Essays on Cross-Cultural ENCOUNTER (1996).
} 
modes of conversion and acculturation. The former describes an encounter where there is a "forced cultural assimilation of the alien population" ${ }^{69}$ in denying difference through the insistence of a universal human nature. The latter is similar and involves "the spreading of diffuse cultural patterns of ways of life," targeting mainly minority groups in a country. ${ }^{70}$ In this manner, the encounter between law and religion rarely leaves the latter unscathed, since the unyielding nature of the law forces religion to acquiesce.

\section{A Critical Reanalysis of Judicial Approaches to Defining Religion}

A good way to begin applying Berger's insights is to critically revisit the different judicial approaches to defining religion as discussed in Section B.I. The aforementioned Singaporean case of Nappalli is a clear example of a form of conversion taking place. What the appellant sees as a religious practice, the court pronounces as philosophical choice. Not only that, but the court precisely denies this difference in opinion by using language that makes it seem commonsensical that the court's opinion should prevail. As Neo puts it, it "essentially imposes a dominant sociocultural attitude concerning religion upon a minority religion." $" 1$

It would appear that the Canadian jurisdiction is more respectful of religions because it allows for religious self-definition up and until the very smallest unit of the individual. Nonetheless, the idea that liberal constitutionalism guarantees a greater degree of religious freedom is undermined by the notion that this perceived "freedom" is only circularly defined by what the constitutional framework itself holds to be "free." In granting religious freedom and claiming tolerance for religious practice, the law does no more than assess the practice to reasonably conform to its own understanding of religion and that the practice does not "meaningfully grate upon any of [its] central commitments." Berger cites the case of Multani v. Commission scolaire MargueriteBourgeoys, which involved an Orthodox Sikh boy whose understanding of his faith required him to wear a kirpan - a small ceremonial dagger - at all times. ${ }^{72}$ His school prohibited this practice as it did not allow students to carry any "weapons and dangerous objects." Because there was a sincerely held belief, it was clear that this policy was against Multani's Charter right to the freedom of religion. The religious expression was made "constitutionally cognizable because it is an aspect of an individual's self-definition and fulfilment and is a function of personal autonomy and choice." ${ }^{73}$ Thus, the question was whether or not there was a reasonable limit to this right under Section 1 of the Charter. The court held that there was no reasonable limit because the manner in which the kirpan was wrapped and sewn in a cloth envelope did not pose a safety concern. It was not so much that the religious practice was accepted by the law, but it was tolerated because it "ought not to be of genuine public concern," 74 and thus already fell within Canadian law's understanding of religion.

In this manner of pronouncing a practice as tolerated, "law asserts its cultural superiority and performs the dominance of public norms." ${ }^{\prime 5}$ And it often does so in an insidious manner. Returning briefly to Donald, in allowing the appellants conscientiously to object to the pledge taking, Gillanders JA stated that, "the infant appellants demonstrate true loyalty and love of country and the flag by standing firmly for the principles of liberty for which it stands."76 In so doing, the court subsumes the meaning of the religious act into its system of constitutionalism and

\footnotetext{
${ }^{69}$ Berger, supra note 15 , at 109 .

${ }^{70}$ BERgER, supra note 15 , at 110 .

${ }^{71} \mathrm{Neo}$, supra note 38 , at 582.

${ }^{72}$ Multani v. Comm'n scolaire Marguerite-Bourgeoys, [2006] 1 S.C.R. 256 (Can.).

${ }^{73}$ BERGER, supra note 15 , at 122.

${ }^{74}$ BERGER, supra note 15 , at 122 .

${ }^{75}$ BERGER, supra note 15 , at 122 .

${ }^{76}$ Donald, supra note 24 , at 522 (emphasis added).
} 
language of individual rights, thereby clandestinely reasserting the primacy of its central commitments.

The acculturation occurring in this instance is closely linked to Michael Walzer's idea of liberalism as a "self-subverting" doctrine. ${ }^{77}$ When the premises of liberal theory regarding state and society is pushed to its end, what results is a "building of a social world less alien to a self that can always violate the generative rules of its own mental or social constructs." 78 In its attempt to create the conditions where freedom of the individual is possible, liberal constitutionalism -in the cases of Donald and Multani - takes away the individual's ability to have religion mean anything but a reaffirmation of the state's own liberal values. This undercutting effect appears benign in these two cases as the outcome was nevertheless in favor of the religious believers. This effect, however, will become more obvious in Sections C.II and C.IV below.

\section{Respect for Group Definitions of Religious Practice in Marriage}

While it is clear that the Canadian courts are reluctant to encroach into the religious realm when it regards an individual's self-definition, it is evident that they are less hesitant when this practice goes against other recognized rights of an individual. Cases considering the Jewish get illustrate this point.

The case of Bruker v. Macrovitz concerned the ability of a wife in a Jewish marriage to enforce a get clause that was entered into upon the couple's divorce in a corollary relief settlement. ${ }^{79}$ This clause was a promise on the part of the husband to obtain a get in order to release his wife religiously from marriage, thereby rendering the laws of adultery inapplicable.

While a unanimous Court of Appeal, as well as two dissenting judges of the Supreme Court, found the issue was non-justiciable before the secular courts as it was an internal religious matter, the majority of the Supreme Court found that the obligation consented to by the husband was an enforceable contractual obligation even though it had religious aspects. The majority had the perspective that this case concerned a valid contractual agreement whose contents were incidentally religious, but nonetheless was subject to conventional contractual principles. The court rejected the husband's argument that this infringed upon his Section 3 Charter rights guaranteeing his religious freedom.

In finding that such religious agreements would be legally enforceable, Justice Abella went beyond the contractual principle of voluntary obligations. She also appeared to have decided based on public policy considerations that supported the removing of impediments to religious divorce and marriage - refusing the operation of the get clause would be against "equality rights," and a "severe impairment [of the wife's] ability to live according to the country's values." ${ }^{20}$ In mitigating the inequities brought about by the gendered asymmetry of these religious rules, it could be said that law has in some ways privileged its own commitments, which has led it to disregard the commitments of the culture it has encountered. As Richard Moon puts it,

\footnotetext{
${ }^{77}$ Michael Walzer, Politics and Passion: Towards a More Egalitarian Liberalism 153 (2004).

${ }^{78}$ Roberto M. Unger, The Critical Legal Studies Movement: Another Time, A Greater Task 125 (2015).

${ }^{79}$ Bruker v. Marcovitz, [2007] 3 S.C.R. 607 (Can.). The court sets out the background of what a "get" clause is in paragraphs 3-5:

A get is a Jewish divorce. Only a husband can give one. A wife cannot obtain a get unless her husband agrees to give it. Under Jewish law, he does so by "releasing" his wife from the marriage and authorizing her to remarry. The process takes place before three rabbis in what is known as a beth din, or rabbinical court. The husband must voluntarily give the get and the wife consent to receive it. When he does not, she is without religious recourse, retaining the status of his wife and unable to remarry until he decides, in his absolute discretion, to divorce her. She is known as an agunah or "chained wife." Any children she would have on civil remarriage would be considered "illegitimate" under Jewish law.

${ }^{80} I d$. at $645-46$.
} 
A commitment to religious freedom involves respecting the individual's spiritual choices and commitments. However, to regard a religious community as an association that members join and quit at will, is to miss both the value of religious association and its potential to limit and sometimes even to oppress its member. ${ }^{81}$

In allowing individual rights and freedoms to trump a religious group's own commitments and rules, perhaps liberal constitutionalism may be impugned as blind to the idea that religion also has a communal character that it has unjustifiably ignored.

\section{Polygamy and Legal Pluralism}

While the preceding analyses would suggest that both jurisdictions' encounters with various religious cultures have hitherto involved some degree of acculturation, ${ }^{82}$ and are therefore equally intolerant to cultural difference, the existence of a separate legal system in Singapore-the Syariah Court-may point to a cross-cultural encounter that Berger would consider "normatively most commendable." 83

The difference in the states' responses to polygamy suggests that Singapore might respect religious freedom more in this context than Canada, and in this regard be more liberal in embracing plural legal orders. Polygamy is made illegal in Canada by virtue of Section 293(1) of the Criminal Code. ${ }^{84}$ The British Columbia Supreme Court quite recently ruled on whether the provision clashes with religious freedom. It found that though the criminalization of polygamy did compromise religious liberty, this was justified because it prevents the harm to children, women, and society. The court ruled in this manner despite its lengthy discussion on both contemporary and historical instances of polygamy in Canada. ${ }^{85}$

In Singapore, though polygamy is not allowed in civil marriages, polygyny is allowed in the context of Muslim marriages. A Muslim man can register marriages with up to four wives with the Registry of Muslim Marriages (ROMM) if he can prove that he has the capability to provide for his wives and provide "specific reasons such as benefits that his first marriage cannot provide, but his second marriage can." 86 This is recognized by the state through the Administration of Muslim Law Act, enacted in 1966. ${ }^{87}$ The ROMM "administers the provisions under the AMLA for marriages solemnized in accordance with the Muslim law and the revocation of divorces where both parties are Muslim." 88

In considering this state of affairs, Gary Bell posits that Canada has much to learn from Singapore's — and Indonesia's — response to multiculturalism. ${ }^{89} \mathrm{He}$ suggests that the lack of legal diversity in Canada is evidence that its policy of multiculturalism has not been successful in some ways. The solution in the face of difference is not a monist, secular, and positivist state law that presents itself as neutral, but instead is the recognition of different legal cultures. ${ }^{90}$ State law, while guaranteeing religious freedom in its constitution, when faced with other cultures, would refuse to

\footnotetext{
${ }^{81}$ Richard Moon, Bruker v. Marcovitz: Divorce and the Marriage of Law and Religion, 42 SuP. CT. L. REv. 37, 62 (2008).

${ }^{82}$ BERGER, supra note 15 , at 109.

${ }^{83}$ BERGER, supra note 15 , at 111 .

${ }^{84}$ Canada Criminal Code, R.S.C. 1985, c C-46.

${ }^{85}$ See Reference re: Section 293 of the Criminal Code of Canada, 2011 CanLII 1588, paras. 337-467 (Can. B.C. S. C.).

${ }^{86}$ Polygyny, REGISTRY OF MUSLIM MARRIAGES (May 10, 2019), https://www.romm.gov.sg/about_marriage/romm_polygyny.asp.

${ }^{87}$ Administration of Muslim Law Act 2009 c. 3 (Sing.) [hereinafter AMLA].

${ }^{88}$ Id.; See also Our History, REgISTRY OF Muslim MARRIAGES (Apr. 2, 2015), https://www.romm.gov.sg/about_romm/ romm_profile.asp.

${ }^{89}$ Gary F. Bell, Multiculturalism in Law is Legal Pluralism-Lessons from Indonesia, Singapore and Canada, SING. J. LEGAL STUD. 315 (2006).

${ }^{90}$ The story of the potential use of religious law, in particular shari'a-based norms, in arbitration in the Province of Ontario is a prominent example of the reaction to religious legal norms being encountered in Canada. See infra Section C.IV.
} 
actually give up any of its ground. Furthermore, as Berger says: "[W]hen toleration of a given religious commitment would require the law to actually cede normative or symbolic territory, law trumps it in the name of procedural fairness, choice autonomy, or the integrity of the public sphere; with this, tolerance gives way to conversion." 91

Thus, no matter the commitments of Singapore's or Canada's state legal culture, the hegemonic nature of the law would only understand and therefore tolerate religious practice when it aligns with the legal culture's own predominant commitments. Thus, no matter the predominant commitments of the jurisdiction's state law, their interaction with religion necessarily leads to their "winning."

Healthier forms of cross-cultural interaction, such as cultural borrowing-which "involves a prolonged, sometimes arduous process of engagement in alien life-forms, a process yielding at least a partial transformation of native habits due to a sustained learning experience" 92 - and dialogical engagement - where both cultures are willing to "undergo a mutual learning process while simultaneously preserving the distinctiveness of difference of their traditions" 93 - requires law to open itself up to being self-critical and self-decentering. But the rule of law's very own efficacy comes from its conceitedness and its refusal to at any point undermine itself-thus, it must always stand above culture. The religious difference of the Other will never actually be accepted by law.

Accordingly, legal pluralism may be the antidote to state law's conceit. For Bell, to determine if a society is legally plural, one must ask if the country does the following:

(1) recognize in their state law that non-state laws govern significant aspects of the life of some of their citizens, (2) recognize that there is a diversity of applicable laws within the same state territory (not the same law is applicable to all citizens) and (3) apply this non-state law or refrain from interfering with its application and recognize its application. ${ }^{94}$

The enactment of the AMLA would appear to symbolize the state's recognition of non-state laws when it comes to Muslim affairs. Bell notes that even this allowance for the diversity of laws does not just include that between state law and Islamic law, but Section 33 of the AMLA also recognizes the existence of some legal pluralism within Islam itself. Thus, though Malays and Indonesians generally follow the Shafi'i school, the tenets of other schools of law would be recognized as well. ${ }^{95}$

The peaceful co-existence of both state law and Syariah law thus enables healthier modes of interaction. Contrary to cases where religion is interpreted by law, the interaction between the two distinct bodies of law within Singapore is non-hierarchical, and therefore does not lead to the assimilation of one into the other. Instead, there is a dialogical mode of encounter, where both laws evolve due to their encounter with the other. Hence, state laws have been recently amended to acknowledge more Islamic law in commercial matters. The Income Tax Amendment Act (No. 34 of 2005) modifies tax law to take into account Islamic financial instruments that are now offered by financial and other institutions. ${ }^{96}$ At the same time, there have been recent amendments to the AMLA in August 2017, which shows the dialogue between state law and the Islamic legal norms. Thus, AMLA now follows the approach in Singapore's Women's Charter that makes marriage education programs compulsory for couples in minor marriages, though these programs would be adapted to be "based on values of the religion and touches on the pillars of marriage in Islam." 97

\footnotetext{
${ }^{91}$ BERGER, supra note 15 , at 131.

${ }^{92}$ BERGER, supra note 15 , at 111 .

${ }^{93}$ BERGER, supra note 15 , at 111 .

${ }^{94}$ BERGER, supra note 15 , at 316 .

${ }^{95}$ Bell, supra note 89 , at 327.

${ }^{96}$ See Bell, supra note 89 , at 327.

${ }^{97}$ Strengthening the Administration of Muslim Law Act, Ministry OF Culture, Community \& YouTH (Mar. 15, 2019), https://www.mccy.gov.sg/news/Parliamentary/2017/Aug/Strengthening-the-AMLA.aspx.
} 


\section{Religious Arbitration and Pluralism}

In contrast to Singapore's acceptance of legal pluralism, the 2002-2005 controversy over religious arbitration in Ontario seems to suggest Canada's insistence on secular law's monopoly over family matters. By way of background, Ontario's 1991 Arbitration Act allowed private individuals to settle a dispute accorded to a type of law of their choosing. Such private arbitration proceedings could be employed to settle disputes for civil matters falling within provincial jurisdiction. These included matters concerning family law, such as spousal separation, financial support for a spouse, or the division of property. Thus, this allowed people of different faiths to approach these arbitration tribunals for redress.

The controversy began when the Islamic Institute of Civil Justice announced its intention to create a body that would provide arbitration services in the areas of family and inheritance law according to Islamic personal law. The proposal also suggested that rulings made would be centralized and standardized.

What ensued was a public outcry with concerns that included the potential for such a body to intrude upon women's rights and the public principle of secularism. To deal with this, former Attorney General of Ontario and former Minister Responsible for Women's Issues, Marion Boyd, was given the mandate to explore the implications of using Islamic personal law in arbitrations.

Though Boyd's report ${ }^{98}$ was in favor of religious tribunals whose practices could be overseen by Canadian institutions, the provincial government eventually disregarded the report and passed legislation to ensure that all family law arbitrations are conducted only under Canadian law. The government justified rejecting the recommendation of the Boyd report by citing the need to protect women's rights. ${ }^{99}$ In effect, all other family law resolutions based on other laws or principles-including religious principles-would have no legal status. ${ }^{100}$ The state of affairs was to be as then Premier Dalton McGuinty put it_- "one law for all Ontarians."101

The Ontarian (and perhaps Canadian) commitment to specific liberal conceptions of individual and private rights is seen to trump those of group rights, and this time with anti-Islamic and anti-multiculturalist sentiment. ${ }^{102}$ Therefore, it is perhaps unfortunate that the government did not take heed of the Boyd report, as its recommendation to allow religious arbitration while providing for safeguards would have-as in the example of the Syariah courts in Singapore-allowed for healthier forms of cross-cultural interaction between the secular and the religious. Such interaction could have accomplished what Boyd envisioned: To accommodate minority groups while balancing the state's "firm commitment to individual agency and autonomy." 103

\section{Multiculturalism, Pluralism, Liberalisms}

We began by noting that both Singapore and Canada are-in fact, and in self-identification and presentation-multicultural. Their different jurisprudence, therefore, might be said to be reflective of different ways in which they have given effect to their multiculturalism, which will always be inevitably contextually sensitive. Multiculturalism, after all, will almost always involve some balancing of the interests of individuals and communities_-or of "the community." Moreover,

\footnotetext{
${ }^{98}$ Dispute Resolution in Family Law: Protecting Choice, Promoting Inclusion, Ministry of ATT’Y Gen. (Dec. 2004), https:// www.attorneygeneral.jus.gov.on.ca/english/about/pubs/boyd/executivesummary.html.

${ }^{99}$ Paul May, The Controversy over Religious Arbitration Tribunals in Ontario: Unspoken Identity-Based Justifications?, 12(1) WORLD POL. SCI. 25, 28 (2016).

${ }^{100}$ Province of Ontario Family Statute Law Amendment Act, S.O. 2006, c. 1 (Can.).

${ }^{101}$ Colin Freeze \& Karen Howlett, McGuinty Government Rules out Use of Sharia Law, Globe \& MaIL (Sept. 12, 2005), https://www.theglobeandmail.com/news/national/mcguinty-government-rules-out-use-of-sharia-law/article18247682/.

${ }^{102}$ Marion Boyd, Religion-Based Alternative Dispute Resolution: A Challenge to Multiculturalism, POL'y OpTIONS 465,471 (Nov. 28, 2007, 1:30PM), http://policyoptions.irpp.org/wp-content/uploads/2014/08/boyd.pdf.

${ }^{103} \mathrm{Id}$. at 470 .
} 
multiculturalism can be institutionally varied, so perhaps Singapore and Canada are engaged in different forms of multiculturalism. ${ }^{104}$ While not rejecting the value of thinking in terms of varieties of multiculturalism, we suggest that considering the impact of liberalism (or lack thereof) and the embrace of pluralism (or lack thereof) is also important. Indeed, these conceptsmulticulturalism, liberalism, and pluralism-interact and cross-cut such that there are versions of multiculturalism that may be more about liberal values, and others more about embracing cultural pluralism. ${ }^{105}$ For instance, when it comes to freedom of religion as one of the key planks supporting Canadian multiculturalism, Section 2 of the Canadian Charter talks about the individual, but not the group. Compare this to Article 15 of the Singaporean Constitution with respect to freedom of religion, which talks both about the person as well as the group. ${ }^{106}$ Furthermore, as discussed below, although some commentators-like Michel Rosenfeld-seem to describe a liberal approach as in opposition to a more desirable pluralist approach, others- such as William Galston and Michael Walzer-see the concept of liberalism itself as capable of accommodating pluralist objectives and values.

In this light, one could spin a deceptively simple story about how Singapore and Canada deal with diversity, which would go something like this: Canada, as a country of the West, embraces liberal values and culture as these are hallmarks of Western legal systems; and Singapore, being outside of the West, does not. In the result, when we consider how this affects religious diversity as freedom of religion is one of the core liberal values, we will see religious diversity robustly present in Canada and in timid or weak form in Singapore. The materials discussed above, however, tell us that the stories are not so simple. Moreover, and perhaps most interestingly, they tell us that the categories of what is a liberal approach or what is secular framework are also not so simple. With respect to the secular, Jocelyn Maclure and Charles Taylor have suggested that it is based upon two major principles: equality of respect, and freedom of conscience; and two operative modes: separation of church and state, and state neutrality towards religions and secular philosophical movements. This is not the only understanding of secularism, however, as Maclure and Taylor acknowledge that others associate secularism with different numbers—and sets—of principles. ${ }^{107}$ They also point out that the ends and operative modes of secularism may enter into conflicts, and that these conflicts have been dealt with in different ways in different countries. ${ }^{108}$

It is also clear that "liberal(ism)" can mean a range of things. Indeed, the Stanford Encyclopedia of Philosophy's entry on liberalism starts by saying forthrightly that: "Liberalism is more than one thing. On any close examination, it seems to fracture into a range of related but sometimes competing visions." ${ }^{109}$ The entry goes on to note that, "[l]iberalism is, of course, usually associated

\footnotetext{
${ }^{104}$ Sara Song, Multiculturalism, Stan. EnCYClopedia Philosophy (Aug. 12, 2016), https://plato.stanford.edu/entries/ multiculturalism/\#ClaMul. Examples of multicultural accommodation can include:

[E]xemptions from generally applicable law (e.g. religious exemptions), assistance to do things that the majority can do unassisted (e.g. multilingual ballots, funding for minority language schools and ethnic associations, affirmative action), representation of minorities in government bodies (e.g. ethnic quotas for party lists or legislative seats, minority-majority Congressional districts), recognition of traditional legal codes by the dominant legal system (e.g. granting jurisdiction over family law to religious courts), or limited self-government rights (e.g. qualified recognition of tribal sovereignty, federal arrangements recognizing the political autonomy of Québec).

${ }^{105} I d$. (discussing different versions of multiculturalism).

${ }^{106}$ See Constitution of the Republic of Singapore Aug. 9, 1965; Canadian Charter of Rights and Freedoms, Part I of the Constitution Act, 1982, being Schedule B to the Canada Act, 1982, c 11 (U.K.).

${ }^{107}$ Jocelyn Maclure \& Charles Taylor, Secularism and Freedom of Conscience 23 (2011).

${ }^{108} I d$. at $24,26$.

${ }^{109}$ Gerald Gaus, Liberalism, Stan. EncyClopedia Philosophy (Jan. 22, 2018), https://plato.stanford.edu/entries/ liberalism/. The entry concludes by saying, in a nicely put way:

Given that liberalism fractures on so many issues - the nature of liberty, the place of property and democracy in a just society, the comprehensiveness and the reach of the liberal ideal—one might wonder whether there is any point in talking of 'liberalism' at all. It is not, though, an unimportant or trivial thing that all these theories take liberty to be the grounding political value. Radical democrats assert the overriding value of equality, communitarians maintain that the demands of
} 
with individualist analyses of society," but also that "liberalism has a long history of seeking to accommodate religious groups that have deep objections to certain public policies, such as the Quakers, Mennonites or Sikhs." 110

These statements-cum-definitions allow us to better consider the situations of Singapore and Canada. It does seem that on the "liberalism as individualist analyses" metric, the Canadian approach is the more liberal precisely because it is centered on the individual and individual understanding of what their religious commitments mean. So, the statements above in Donald, Amselem, and Multani emphasized the individual understanding of what their religious tradition is. As already mentioned, these statements sit in a rather apparent contrast to the Singapore Court of Appeal's decision in Nappalli. But what happens when we consider the accommodation of religious groups and the religious liberty that can emerge from these groups-or to put it more sharply from individuals within these groups-being allowed to express their religious diversity? Which jurisdiction is more liberal in the sense of accommodating diversity in this context? This would be a liberalism of plurality-or indeed of the embrace legal pluralism. In this light, the answers considered above may be different.

The standard understandings of legal pluralism emphasize the existence of different legal orders or systems within one jurisdictional space. Thus, conventional legal pluralism is about the fact of plurality as well as the toleration of this fact. By toleration, we mean that descriptive legal pluralism implies that legal variety is present and accepted as a matter of fact, though it does not necessarily imply that legal variety is welcomed. To the extent that descriptive legal pluralism has normative implications, it points to the presence of normatively different legal regimes in one jurisdictional space. Here, it is the fact of normative heterogeneity that is highlighted, not the desirability—or non-desirability—of the heterogeneity.

It is on this basis that we believe it may be better to term a situation of descriptive legal pluralism as above discussed a condition of plurality, using this word to capture the existence of plural legal phenomena as fact. In contrast, the word pluralism, like others "isms," would then be reserved for a situation with more profound normative implications, and suggest not just the toleration of legal diversity, but rather a positive normative attitude or response to the factual situation of plurality. Pluralism then would welcome or embrace plurality, not just tolerate it. In short, while plurality may be a fact, pluralism is an attitude of a particular type, and hence, a choice. ${ }^{111}$ Thus, the standard for pluralism has to be seen as qualitatively different from the mere condition of plurality. Rather than the tolerance of plurality, pluralism would entail the affirmation of the normative legitimacy of legal differences and the authority bases for these differences; we would move from tolerance to acceptance. Proceeding with these terms will allow us to make analytical distinctions as we consider the cases of Singapore and Canada.

As the example of the presence of AMLA and the institution of the Syariah Courts suggests, it is Singapore, rather than Canada, that is embracing legal pluralism more robustly in allowing for legislative and institutional recognition of some religious law-even if this is not provided to all of its communities. Indeed, the contrast between Singapore and Canada is made even stronger in light of the religious arbitration debate discussed in Section C.IV above. Thus, is it Singapore that is more "liberal" - at least on this measure?

Instead of locating this difference on a spectrum of how "liberal" the jurisdictions are with respect to their response to diversity, Michel Rosenfeld would characterize the difference as a liberal (Canada) versus pluralist (Singapore) handling of the "illiberal"' religious

\footnotetext{
belongingness trump freedom, and conservatives complain that the liberal devotion to freedom undermines traditional values and virtues and so social order itself. Intramural disputes aside, liberals join in rejecting these conceptions of political right.

${ }^{110} \mathrm{Id}$.

${ }^{111}$ Arif A. Jamal, Moving out of Kazanistan: Liberal Theory and Muslim Contexts, in MUSLIM SOCIETIES AND THE Challenge of Secularization-An InTerdisciplinary Approach 83, 91 (Gabriele Marranci ed., 2010).
} 
communities. ${ }^{112}$ Under Rosenfeld's conception, pluralism, unlike liberalism, does not have preference for the individual over the group (nor vice versa). Instead, pluralism views all conceptions of the good-regardless of whether it is religious or non-religious, or individual or group - as of equal worth. Hence, just because a religious community is "illiberal" does not, for the pluralist, justify intervention from the outside. The pluralist would be satisfied with this state of affairs so long as there is a general right of exit to all of the group's members, because it recognizes that subordination from one perspective may not be subordination from another, and that the denial of recognition to group-regarding differences may inhibit the deployment of pluralism. ${ }^{113}$

Though a liberal handling is observed in the Canadian examples cited, it is notable that room for the adoption of such a pluralist approach exists in the Canadian context. This is supported by Section 27 of the Canadian Charter, which states: "This Charter shall be interpreted in a manner consistent with the preservation and enhancement of the multicultural heritage of Canadians." 114 One might think, therefore, that this provision may be used actively by the Canadian judiciary to push for diversity and pluralism in Canada. In fact, however, according to Canada's Department of Justice, "[c] ase law has not provided detailed commentary on the purpose of Section 27 beyond that which can be gathered from a reading of its text." 115 This is not to say that Section 27 has received no judicial consideration. The Department of Justice mentions several cases where the Supreme Court of Canada has looked at Section 27. But consider what work it has done; as the Department's website says:

The Supreme Court has referred to the values of multiculturalism enshrined by section 27 as being related to a state duty of religious neutrality (Mouvement laïque québécois v. Saguenay (City), [2015] 2 S.C.R. 3). Section 27 also has been cited as a consideration in determining the circumstances under which a woman may be permitted to wear a niqab while testifying at a criminal trial (R. v. N.S., 2010 ONCA 670, aff d, [2012] 3 S.C.R. 726, albeit without reference on this point by the majority of the Supreme Court, but with mention by LeBel J. concurring in the result). ${ }^{116}$

This analysis is rather interesting; it suggests to us that Section 27 has not been invoked to enhance legal pluralism, but rather it either has not been a key part of the Supreme Court of Canada's reasoning - in $R v$. N.S. - or has been used to buttress the state's duty of religious neutrality-in Saguenay. To be fair, in Saguenay, the Court felt that state religious neutrality was important to secure diversity. It said: "Section 27 requires that the state's duty of neutrality be interpreted not only in a manner consistent with the protective objectives of the Canadian Charter but also with a view to promoting and enhancing diversity."117

\section{E. Conclusion}

The seemingly contrasting approaches to addressing religious diversity in Singapore and Canada both emerge out of contexts that are-in social fact as well as in political presentation-multicultural and multi-religious, and in both jurisdictions, there are legal commitments to freedom of

\footnotetext{
${ }^{112}$ Michel Rosenfeld, Recasting Secularism as One Conception of the Good Among Many in a Post-Secular Constitutional Polity, in Constitutional Secularism in an Age of Religious Revival 79, 101 (Susanna Mancini \& Michel Rosenfeld eds., 2014).

${ }^{113} \mathrm{Id}$. at 102.

${ }^{114}$ Canadian Charter of Rights and Freedoms, Part I of the Constitution Act, 1982, being Schedule B to the Canada Act, 1982 , c $11, \S 27$ (U.K.).

${ }^{115}$ Id. at art. 27.

${ }^{116}$ Section 27-Multicultural Heritage, CAN. DEP'T OF JUST. (June 17, 2019), https://www.justice.gc.ca/eng/csj-sjc/rfc-dlc/ccrfccdl/check/art27.html.

${ }^{117}$ Mouvement laïque québécois v. Saguenay, [2015] 2 S.C.R. 3, para. 74 (Can.).
} 
religion. Nevertheless, these commitments are manifested differently. That this should be so is not surprising. Context matters, and Singapore and Canada exist in different contexts. Our inquiry here is, however, more nuanced, and seeks to explore how we should understand the different approaches.

As shown in the preceding discussion, Singapore appears to give wider recognition or appreciation to community/ies. For instance, in the example of taking the national pledge, the norms of Singaporean society as a whole can seemingly outweigh individually constructed understanding. So too in the situation of taking offense where the Singapore formula weighs community concerns more heavily than individual rights. Moreover, Singapore is also willing to formalize its recognition of community norms - at least for its Muslim community-through the AMLA and the establishment of the Syariah Court. The Canadian pattern-as we have seen-is different, and gives primacy to individual conceptions, rights, and interests, ahead of community norms. It is individual understandings of what a religious tradition means that are highlighted in legal consideration.

Now, if we locate the core of the liberal position in the locus of the individual versus the community (or communities), then we might say that the Canadian model is indeed more liberal than that of Singapore. This, of course, is the classical distinction between liberals and communitarians. ${ }^{118}$ In framing this discussion, William Galston says: "Liberalism requires a robust though rebuttable presumption in favor of individuals and groups leading their lives as they see fit, within a broad range of legitimate variation, in accordance with their own understanding of what gives life meaning and value."119

We might, however, consider a liberal outlook to be one that is above diversity, and indeed scholars like Galston seem to argue precisely for this in saying:

Properly understood, liberalism is about the protection of legitimate diversity .... What we need instead is an understanding of liberalism that gives diversity its due. This understanding is expressed in public principles, institutions, and practices that afford maximum feasible space for the enactment of individual and group differences, constrained only by the ineliminable requirements of liberal social unity. ${ }^{120}$

This framing of liberalism may be about fostering pluralism, and-in particular-embracing some form of legal pluralism. This might be in line with Walzer's notion of liberalism, which because of its self-subverting nature, requires continual communitarian corrections. In arguing for a more egalitarian liberalism, he writes:

[C] ommunities are the sites of an intense common life that is, apparently, valued by most of its participants, even if they haven't chosen it. Toleration in a democracy involves acknowledging that evaluation; egalitarianism is well served, I believe, by the same acknowledgement, which its political defenders express by focusing on the group, as well as on the individual members.... We don't have to, we shouldn't, and we probably can't force individuals to be free. ${ }^{121}$

This requires the recognition that the pre-commitments of the liberal state do not always take precedence over those of the community. For if this were so, it would turn the democratic citizens

\footnotetext{
${ }^{118}$ The literature is replete on this debate, but for an enduring collection of essays that discuss these positions, see Liberalism AND Its Critics (Michael J. Sandel ed., 1984).

${ }^{119}$ William A. Galston, Liberal Pluralism: The Implications of Value Pluralism for Political Theory and Practice 3 (2002).

${ }^{120} I d$. at 23 (emphasis added).

${ }^{121}$ WALZER, supra note 77 , at 60 .
} 
into "something much too close to a totalizing community." 122 It would be contrary to liberalism's own premises to view individuals that have divergent or conservative practices as immediately lacking in any agency.

For Walzer, liberalism's flaws need only require a periodic communitarian correction, and it would not be helpful to suggest that it can replaced by some "preliberal or antiliberal community waiting somehow just beneath the surface or beyond the horizon." He found that in the American context, "there is no one out there but separated, rights-bearing, voluntarily associating, freely speaking, liberal selves." Thus, Walzer sees any meaningful correction of liberalism as simply a "pursuit of the intimations of community" within the individual - a selective reinforcement of liberalism's own values. ${ }^{123}$

This can, therefore, be contrasted to the comprehensive pluralist approach Rosenfeld takes, which perhaps does not require a steadfast ontological commitment to the "liberal self." As previously stated, such a conception of pluralism has no bias for the individual over the group. It views all conceptions of the good as having an ex ante equal claim to full recognition, though this claim may not be realized ex post if it fails the "standard of peaceful coexistence among the greatest possible number of competing conceptions of the good within the relevant polity." 24

As mentioned, the concepts of liberalism and pluralism intersect in complex ways and are susceptible differing uses by different commentators. To determine the implications of the adoption of these different approaches to the constitutional ordering of each jurisdiction would warrant another Article in itself. We preliminarily observe that Walzer's approach would sit more comfortably in the Canadian context given its commitment to the "liberal self." This would be much less so in the Singapore context, given that some observers would not consider the polity to be "liberal" in the first place. ${ }^{125}$

Finally, reflecting on the principles of secularism mentioned by Maclure and Taylor, we may question whether, in addressing and fostering diversity, it is desirable for the state to be secular and benignly inactive - which seems akin to the Canadian state-or for the state to be secular and benignly proactive - which seems more akin to the Singaporean state. This would further beg the question of which of these positions is not only the more liberal, but indeed the more desirable, especially if we want to foster solidarity in diversity.

\footnotetext{
${ }^{122}$ WALZER, supra note 77 , at 56.

${ }^{123}$ Michael Walzer, The Communitarian Critique of Liberalism, 18(1) Pol. THEory 6 (2018).

${ }^{124}$ Rosenfeld, supra note 112 , at 81.

${ }^{125}$ See, e.g., Li-Ann Thio, Constitutionalism in Illiberal Polities, in The Oxford Handbook OF Comparative Constitutional Law 133, 144 (Michel Rosenfeld \& András Sajó, eds., 2012).
}

Cite this article: Jamal AA, Sheng Jie DW (2019). A Tale of Two (Diverse) Countries: Religious Diversity in Canada and Singapore. German Law Journal 20, 986-1006. https://doi.org/10.1017/glj.2019.74 